\title{
Potentiation of $\beta$-Adrenergic Signaling by Adenoviral-mediated Gene Transfer in Adult Rabbit Ventricular Myocytes
}

\author{
Mark H. Drazner, ${ }^{\star}$ Karsten C. Peppel, ${ }^{\ddagger}$ Sara Dyer, Augustus O. Grant, ${ }^{\star}$ Walter J. Koch, ${ }^{\S}$ and Robert J. Lefkowitz ${ }^{\star \ddagger}$ \\ Howard Hughes Medical Institute, *Department of Medicine (Cardiology), ${ }^{\ddagger}$ Department of Biochemistry, and ${ }^{\S}$ Department of Surgery, \\ Duke University Medical Center, Durham, North Carolina 27710
}

\begin{abstract}
Our laboratory has been testing the hypothesis that genetic modulation of the $\beta$-adrenergic signaling cascade can enhance cardiac function. We have previously shown that transgenic mice with cardiac overexpression of either the human $\beta_{2}$-adrenergic receptor $\left(\beta_{2} \mathrm{AR}\right)$ or an inhibitor of the $\beta$-adrenergic receptor kinase $(\beta \mathrm{ARK})$, an enzyme that phosphorylates and uncouples agonist-bound receptors, have increased myocardial inotropy. We now have created recombinant adenoviruses encoding either the $\beta_{2} \mathrm{AR}$ (Adeno- $\beta_{2} \mathrm{AR}$ ) or a peptide $\beta \mathrm{ARK}$ inhibitor (consisting of the carboxyl terminus of $\beta$ ARK1, Adeno- $\beta$ ARKct) and tested their ability to potentiate $\beta$-adrenergic signaling in cultured adult rabbit ventricular myocytes. As assessed by radioligand binding, Adeno- $\beta_{2} \mathrm{AR}$ infection led to $\sim 20$-fold overexpression of $\beta$-adrenergic receptors. Protein immunoblots demonstrated the presence of the Adeno- $\beta$ ARKct transgene. Both transgenes significantly increased isoproterenolstimulated cAMP as compared to myocytes infected with an adenovirus encoding $\beta$-galactosidase (Adeno- $\beta \mathrm{Gal}$ ) but did not affect the sarcolemmal adenylyl cyclase response to Forskolin or NaF. $\beta$-Adrenergic agonist-induced desensitization was significantly inhibited in Adeno- $\beta$ ARKct-infected myocytes $(16 \pm 2 \%)$ as compared to Adeno- $\beta$ Gal-infected myocytes $(37 \pm 1 \%, P<0.001)$. We conclude that recombinant adenoviral gene transfer of the $\beta_{2} \mathrm{AR}$ or an inhibitor of $\beta A R K-m e d i a t e d$ desensitization can potentiate $\beta$-adrenergic signaling. (J. Clin. Invest. 1997. 99:288-296.) Key words: gene therapy $\bullet \beta$-adrenergic receptor - myocardium $\cdot$ cultured cells $\bullet$ congestive heart failure
\end{abstract}

This work was presented in part at the 68th Scientific Sessions of the American Heart Association from 13-16 November 1995 in Anaheim, CA and was published in abstract form (1995. Circulation. Suppl. 92:I-502).

M.H. Drazner's present address is Brigham and Women's Hospital, Cardiovascular Division, Department of Medicine, 75 Francis Street, Boston, MA 02115.

Address correspondence to Dr. Robert J. Lefkowitz, Howard Hughes Medical Institute, Duke University Medical Center, Box 3821, Durham, NC 27710. Phone: 919-684-2974. FAX: 919-684-8875. E-mail: lefko001@ mc.duke.edu

Received for publication 4 March 1996 and accepted in revised form 15 November 1996.

J. Clin. Invest.

(C) The American Society for Clinical Investigation, Inc.

0021-9738/97/01/288/09 \$2.00

Volume 99, Number 2, January 1997, 288-296

\section{Introduction}

The activation of $\beta$-adrenergic receptors $(\beta \text {-ARs })^{1}$ by catecholamines is a critical event in the regulation of cardiac function. Transduction of this signal is mediated by heterotrimeric guanine nucleotide binding $(\mathrm{G})$ proteins and includes the generation of second messengers such as cAMP. In turn, cAMPdependent protein kinase (PKA) is activated and phosphorylates proteins including L-type voltage-dependent calcium channels (1) and phospholamban (2), leading to enhanced cardiac chronotropy and inotropy. Though the $\beta_{1}$-AR is the predominant subtype present in the myocardium, $\sim 20-30 \%$ of total cardiac $\beta$-ARs are $\beta_{2}$-ARs and they too contribute to the regulation of cardiac function (3), possibly through a distinct intracellular pathway $(4,5)$.

Congestive heart failure $(\mathrm{CHF})$ is a clinical syndrome that confers significant morbidity and mortality despite recent advances in medical therapy (6). Numerous abnormalities in the $\beta$-AR signaling cascade occur in this syndrome including a selective downregulation of $\beta_{1} \mathrm{ARs}(7,8)$ and an upregulation of the $\beta$-adrenergic receptor kinase $(\beta A R K)$, an enzyme that specifically phosphorylates and uncouples the activated $\beta$-AR $(9,10)$. Modulation of this pathway to improve cardiac inotropy is being explored by our laboratory as a novel therapeutic approach for CHF. Transgenic mice with selective cardiac overexpression of either the human $\beta_{2} A R$ (11) or an inhibitor of $\beta$ ARK (12) have enhanced contractility. The current study was undertaken to explore whether recombinant adenoviralmediated transfer of these transgenes would be able to potentiate $\beta$-adrenergic signaling in cultured adult rabbit ventricular myocytes.

\section{Methods}

Myocyte isolation and culture. All studies with rabbits were approved by the institutional review board at Duke University. Adult male New Zealand white rabbits were anesthetized, treated with heparin, and then intubated. The heart was excised and perfused by the Langendorff technique with Joklik's modified MEM containing hyaluronidase, collagenase, protease, and $12.5 \mu \mathrm{M} \mathrm{CaCl}_{2}$ as previously described in references 13 and 14 . When the heart turned soft, the ventricles were dissected free and agitated into a solution of Joklik's MEM with $10 \%$ fetal bovine serum. Cells were allowed to settle by gravity twice in $10 \mathrm{ml}$ of culture medium (medium 199 with Earle's salts, $25 \mathrm{mM}$ Hepes, and sodium bicarbonate without glutamine

1. Abbreviations used in this paper: Adeno- $\beta_{2} \mathrm{AR}$, Adenovirus encoding human $\beta_{2}$-adrenergic receptor; Adeno- $\beta$ ARKct, Adenovirus encoding $\beta \mathrm{ARK}_{\mathrm{ct}}$ transgene; Adeno- $\beta \mathrm{Gal}$, Adenovirus encoding a $\beta$-galactosidase transgene; $\beta \mathrm{AR}, \beta$-adrenergic receptor; $\beta \mathrm{ARK}$, $\beta$-adrenergic receptor kinase; $\beta$ ARKct, carboxyl terminus fragment of bovine $\beta$ ARK1; CHF, congestive heart failure; CMV, cytomegalovirus; ISO, (-)-isoproterenol. 
[Sigma Chemical Co., St. Louis, MO] containing 10\% fetal bovine serum [GIBCO BRL, Gaithersburg, MD], $10 \mu \mathrm{M}$ cytosine $\beta$-D-arabinofuranoside [ARA-C; Sigma Chemical Co.], $100 \mathrm{IU} / \mathrm{ml}$ penicillin, and $100 \mu \mathrm{g} / \mathrm{ml}$ streptomycin [Sigma Chemical Co.]). This procedure typically yielded $1-2 \times 10^{7}$ myocytes per rabbit heart, with $50-80 \%$ in a rod-shaped morphology. Myocytes were plated at a density of $1 \times$ $10^{5} / 35 \mathrm{~mm}$ well or $1 \times 10^{6} 100 \mathrm{~mm}$ well on tissue culture plates that were precoated with $20 \mu \mathrm{g} / \mathrm{ml}$ of mouse laminin (GIBCO BRL) for $1 \mathrm{~h}$. The myocytes were calcium tolerant as evidenced by their quiescent state throughout the experiments.

Adenoviral construction. Preparation of the $\beta$-galactosidase adenovirus (Adeno- $\beta \mathrm{Gal}$ ) (see Fig. 1) has been described in reference 15 . The adenoviral backbone for Adeno- $\beta_{2}$ AR and Adeno- $\beta$ ARKct was a replication-deficient "first-generation" adenovirus with deletions of the E1 and E3 genes. It contains the cytomegalovirus (CMV) promoter and bovine growth hormone polyadenylation (bGH) site separated by a polylinker containing a unique XbaI site. The Adenoempty vector does not contain an insert in the polylinker region. 100 $\mu \mathrm{g}$ of Adeno-empty vector DNA was prepared by digestion of a large scale preparation of this virus (see below) with proteinase K (Sigma Chemical Co.) in the presence of $0.5 \%$ SDS at $55^{\circ} \mathrm{C}$ for $2 \mathrm{~h}$, followed by phenol/chloroform (1:1 ratio) extraction and ethanol precipitation. This was then digested by XbaI overnight and the large fragment containing the bGH and adenovirus map units 9.3-100 was gel purified on a $0.6 \%$ agarose gel. This fragment served as the "right end" of both Adeno- $\beta_{2} A R$ and Adeno- $\beta$ ARKct. The "left ends" of these viruses were constructed uniquely. For Adeno- $\beta_{2} A R$, plasmid pCMV4 (16) was digested by SpeI and XbaI. The resulting 740-bp band was subcloned into plasmid pACCMV (gift of Dr. Robert Gerard, University of Texas Southwestern Medical Center, Dallas, TX) creating plasmid pACCMV4. The human $\beta_{2} \mathrm{AR}$ (11) was PCR amplified using primers 5'-AATTGAATTCCCAGACTGCGCGCCATGG-3' and 5'-ATATTCTAGATGCAGGTGGACTGCTACC-3', digested with EcoRI and XbaI, and then subcloned into plasmid pACCMV4. This construct was then digested with $\mathrm{PvuI}$ and $\mathrm{XbaI}$ and the fragment (Adeno- $\beta_{2} \mathrm{AR}$ "left end") containing adenovirus map units $0.0-1.3$, the CMV promoter, the AMV translational enhancer derived from plasmid pCMV4, and the human $\beta_{2} \mathrm{AR}$ was gel purified. For the "left end" of Adeno- $\beta A R K c t$, plasmid pACCMV4 was PCR amplified with primers 5'-AATGCCGGCGTTTAAACATCATCAATAATATACC-3' and 5'-AATTCTAGATTAATTAAGCTAGCCTAGGATCCCCGGGTACCGAG-3', digested with NgoMI and XbaI, and subcloned into plasmid pBluescript SK (Strategene, La Jolla, CA) creating plasmid pSKAC. The $\beta A R K 1$ carboxyl terminus fragment ( $\beta$ ARKct; 17$)$ was digested with EcoRI and XbaI and subcloned into pSKAC. The resulting construct was digested with PmeI and XbaI, and the fragment (Adeno- $\beta$ ARKct "left end") containing adenovirus map units $0.0-1.3$, the CMV promoter, the AMV translational enhancer, and $\beta$ ARKct was gel purified. Approximately $100 \mathrm{ng}$ of the appropriate gel-purified "left end" fragment of Adeno- $\beta_{2} A R$ or Adeno- $\beta$ ARKct was then ligated to $\sim 1 \mu \mathrm{g}$ of the "right end" fragment overnight at $16^{\circ} \mathrm{C}$. The ligation mixture was transfected onto a single $60 \mathrm{~mm}$ dish of 293 human embryonal kidney cells (18) using lipofectamine (GIBCO BRL). The plate was allowed to lyse without an agar overlay. Individual viruses were then isolated by two consecutive rounds of plaque purification using an agar overlay.

After isolation, individual viruses were prepared at large scale by infecting $40150 \mathrm{~mm}$ plates of EBNA transfected 293 cells (Invitrogen Corp., San Diego, CA) with the appropriate virus at a multiplicity of infection (moi) of three. 36-48 $\mathrm{h}$ after infection, when the majority of the cells were floating, the cells were harvested by gentle scraping and collected by a $5 \mathrm{~min}$ centrifugation at $1,000 \mathrm{~g}$ in a GSA rotor. The cell pellet was resuspended in $20 \mathrm{mM}$ Tris $\mathrm{HCl}, \mathrm{pH}$ 7.4, 2 mM EDTA, $\mathrm{pH}$ 8.0 , and the cells were homogenized with 20 strokes in a Dounce homogenizer. DNase A was added to $100 \mu \mathrm{g} / \mathrm{ml}$ and the homogenate was incubated at room temperature for $5 \mathrm{~min}$. The nuclei were removed by centrifugation at $2,500 \mathrm{~g}$ for $10 \mathrm{~min}$. $\mathrm{CsCl}$ was added to the supernatant to $0.3 \mathrm{~g} / \mathrm{ml}$ and the supernatant was then layered on top of a $\mathrm{CsCl}$ step gradient $(1.3$ and $1.4 \mathrm{~g} / \mathrm{ml}$ prepared in virus storage buffer [VSB] $137 \mathrm{mM} \mathrm{NaCl}, 20 \mathrm{mM}$ Tris $\mathrm{HCl}, \mathrm{pH}$ 7.4, $5 \mathrm{mM} \mathrm{KCl}$, and $1 \mathrm{mM} \mathrm{MgCl}$ ) and centrifuged for $2 \mathrm{~h}$ at $32 \mathrm{~K} \mathrm{rpm}$ in a Sorvall Instruments Div. (Newton, CT) TH 64 rotor. The virus band that formed at the $1.3-1.4 \mathrm{~g} / \mathrm{ml}$ interphase was removed with a 16 gauge needle. The virus preparation was layered on top of a $2 \mathrm{ml}$ bed of Cl-6B (Pharmacia Fine Chemicals, Piscataway, NJ) prepared in a $3 \mathrm{ml}$ syringe and centrifuged for 2 min at 1,000 rpm in a Beckman Instruments, Inc. (Fullerton, CA) tabletop centrifuge. This step was repeated once more and the virus concentration was adjusted to $1 \times 10^{11}$ plaque forming units (pfu) $/ \mathrm{ml}$ in VSB. Sucrose was added to $10 \%$ final and the virus preparation was stored in aliquots at $-80^{\circ} \mathrm{C}$. Each aliquot was used a maximum of two times and discarded. Adenoviral titers were determined using plaque titration on HEK 293 cells (17). Alternatively, plaque titers were estimated by determining the absorbance at $260 \mathrm{~nm}\left(\mathrm{pfu} / \mathrm{ml}=\mathrm{A}_{260} \times\right.$ dilution $\left.\times 10^{10}\right)$ of the final viral preparation.

Adenoviral infection. After myocytes became adherent to the tissue culture plates ( $\sim 5 \mathrm{~h}$ after harvesting), they were infected with an appropriate titer of adenovirus in $1 \mathrm{ml}$ medium 199. After $1 \mathrm{~h}$, without aspirating the adenoviral-containing medium, culture medium was added back to the plates.

Cellular viability after adenoviral infection. $36 \mathrm{~h}$ after adenoviral infection, the medium was aspirated and the plates were washed twice with PBS. $1.5 \%$ glutaraldehyde in 50\% PBS (19) was added to the plates as a fixative. The number of rod-shaped or round myocytes was counted at a magnification of 200. 20 fields per plate were counted. Only myocytes fully visible within the field were counted. Rod-shaped myocytes included those in which the length of the cell was at least two times its width with an overall linear morphology. Myocytes with mild end-plate changes were not excluded if the overall morphology met the above conditions. Only round myocytes that were at least one-half the size of the average round myocyte in a field were counted (to exclude cellular debris). To verify adenoviral infection in these experiments, transgene expression from concurrently infected plates was demonstrated as described below.

$\beta$-Galactosidase expression. $36 \mathrm{~h}$ after adenoviral infection, cells were fixed in $0.5 \%$ glutaraldehyde in $50 \%$ PBS for 5 min at room temperature, and then stained with $10 \mathrm{mM} \mathrm{K}_{4} \mathrm{Fe}(\mathrm{CN})_{6}, 10 \mathrm{~mm}$ $\mathrm{K}_{3} \mathrm{Fe}(\mathrm{CN})_{6}, 2 \mathrm{mM} \mathrm{MgCl}$, and $1 \mathrm{mg} / \mathrm{ml} \mathrm{X-gal} \mathrm{(5-bromo-4-chloro-3-indo-}$ lyl- $\beta$-d galactopyranoside) (20) in PBS for $30 \mathrm{~min}$ at $37^{\circ} \mathrm{C}$. The staining solution was then aspirated and the cells were permanently fixed in $1.5 \%$ glutaraldehyde in $50 \%$ PBS.

Immunoblotting. $36 \mathrm{~h}$ after adenoviral infection, cells were harvested in lysis buffer ( $5 \mathrm{mM}$ Tris- $\mathrm{HCl}, \mathrm{pH} 7.4$, and $5 \mathrm{mM}$ EDTA) and Dounce homogenized with 10 strokes on ice. Samples were centrifuged 40,000 $g$ to pellet membranes and supernatants were concentrated in a Centricon-10 (Amicon, Beverly, MA) at 5,000 $\mathrm{g}$ for $30 \mathrm{~min}$ at $4^{\circ} \mathrm{C}$. The membrane fraction was resuspended in $75 \mathrm{mM}$ Tris- $\mathrm{HCl}$, $\mathrm{pH} 7.4,12.5 \mathrm{mM} \mathrm{MgCl}_{2}$, and $2 \mathrm{mM}$ EDTA. Protein concentration was determined by Bradford's method (21). For detection of the Adeno$\beta$ ARKct transgene, $5 \mu \mathrm{g}$ of the cytosolic extracts were electrophoresed on a $12 \%$ SDS-polyacrylamide gel and transferred to a nitrocellulose membrane. As described in reference 17, a rabbit polyclonal anti-serum that recognizes the carboxyl terminus of $\beta$ ARK was used as a primary antibody and chemiluminescent detection was achieved via an alkaline-phosphatase conjugated goat anti-rabbit IgG (Bio$\mathrm{Rad}$, Hercules, CA). For detection of membrane $\mathrm{G}$ protein levels, 50 $\mu \mathrm{g}$ of the membrane fraction were loaded on 4-20\% SDS/polyacrylamide denaturing protein gels and electrophoresed, followed by electro-transfer to nitrocellulose membranes. Primary polyclonal antiserum used at 1:2,000 dilution was anti-Gs $\alpha$ (sc-262; Santa Cruz Biotechnology, Santa Cruz, CA) or anti-Gi $\alpha_{3}$ (sc-823; Santa Cruz Biotechnology). The anti-Gi $\alpha_{3}$ does cross react with other Gi $\alpha$ subtypes. Standard chemiluminescent detection was achieved with an ECL kit (Amersham Inc., Arlington Heights, IL).

Radioligand binding. Cells were harvested $36 \mathrm{~h}$ after adenoviral infection and lysed as above. Nuclei were pelleted at $500 \mathrm{~g}$. Crude 
membranes were prepared by centrifugation at 40,000 $\mathrm{g}$ and then resuspended in $\beta$-binding buffer (75 mM Tris- $\mathrm{HCl}, \mathrm{pH} 7.4,12.5 \mathrm{mM}$ $\mathrm{MgCl}_{2}$, and $2 \mathrm{mM}$ EDTA). $\beta$-AR density was determined by incubation of membranes with a saturating concentration $(\sim 300 \mathrm{pM})$ of $\left.{ }^{125} \mathrm{I}\right]$ cyanopindolol (Dupont-NEN, Boston, MA) for $1 \mathrm{~h}$ at $37^{\circ} \mathrm{C}$ as described in reference 11 except that $10 \mu \mathrm{M}$ alprenolol was used to determine nonspecific binding. Specific binding was normalized to membrane protein. To determine receptor affinity for CYP, saturation isotherms were carried out with increasing concentrations of $\left[{ }^{125} \mathrm{I}\right]$ cyanopindolol $(9-360 \mathrm{pM})$ in the absence and presence of 10 $\mu \mathrm{M}$ alprenolol.

Intracellular cAMP assay. Cells were labeled overnight in 1.5 $\mu \mathrm{Ci} / \mathrm{ml}\left[{ }^{3} \mathrm{H}\right]$ adenine (Dupont-NEN) in medium 199 and then preincubated in MEM (GIBCO BRL) containing $10 \mathrm{mM}$ Hepes (GIBCO BRL) and $1 \mathrm{mM} 3$-isobutyl-1-methylxanthine (IBMX) (Sigma Chemical Co.) for $30 \mathrm{~min}$. Subsequently, the cells were stimulated with 10 $\mu \mathrm{M}$ (-)-isoproterenol (ISO) at $37^{\circ} \mathrm{C}$ in medium containing $100 \mu \mathrm{M}$ ascorbic acid except in the ISO dose-response experiment where the ISO concentration used is explicitly stated. In some experiments either the selective $\beta_{2}$ antagonist, $100 \mathrm{nM}$ ICI 118, 551 (Research Biochemicals International, Natick, MA) or the selective $\beta_{1}$ antagonist, 1 $\mu \mathrm{M}$ ICI 89.406 (Cambridge Research Biochemicals, Wilmington, DE) was included in the preincubation and stimulation steps. In another series of experiments, myocytes were handled as above except that they were stimulated for 5 min with $100 \mu \mathrm{M}$ forskolin in the absence of ascorbic acid. The medium containing either ISO or forskolin was aspirated at the designated time point and $1 \mathrm{ml}$ of ice-cold stop solution $\left(2.5 \%\right.$ perchloric acid, $100 \mu \mathrm{M} \mathrm{cAMP}, 10,000 \mathrm{cpm}{ }^{14} \mathrm{C}$ ) was added to each well. cAMP was determined by anion exchange chromatography and a percent incorporation of the total ${ }^{3} \mathrm{H}$ uptake into $\left[{ }^{3} \mathrm{H}\right]$ cAMP was calculated $(22,26)$. In some experiments, data were standardized such that the percent conversion in control myocytes (uninfected or Adeno- $\beta \mathrm{Gal}$-infected myocytes) was arbitrarily set at one, and all other values were described as a relative amount of cAMP to control.

Desensitization protocol. Myocytes were labeled as above except $10 \mu \mathrm{Ci} / \mathrm{ml}$ of $\left[{ }^{3} \mathrm{H}\right]$ adenine was used. All media were prewarmed to $37^{\circ} \mathrm{C}$. For each condition described below, a percent conversion of total ${ }^{3} \mathrm{H}$ to $\left[{ }^{3} \mathrm{H}\right] \mathrm{cAMP}$ was determined (as in the intracellular cAMP assay). The myocytes were prestimulated either with MEM containing no agonist (naive cells) or $10 \mu \mathrm{M}$ ISO (prestimulated cells). This medium was then aspirated at $10 \mathrm{~min}$ and each well was washed twice with MEM. Medium with no additives was then added to half of the naive cells (basal) and medium containing $10 \mu \mathrm{M}$ ISO to the other half of the naive cells (naive/stimulated). After 3 min the second incubation was terminated by aspiration of medium and the addition of 1 $\mathrm{ml}$ of cold stop solution (see above). ISO-induced cAMP from naive cells was calculated as ([naive/stimulated] - [basal]). The prestimulated cells were handled in an analogous fashion; i.e., after prestimulation, half were incubated for 3 min with medium only (prestimulated only) and half were restimulated with $10 \mu \mathrm{M}$ ISO (prestimulated/ restimulated). The incubation was terminated with aspiration and addition of cold stop solution. ISO-induced cAMP from prestimulated cells was calculated as ([prestimulated/restimulated] - [prestimulated only]). Desensitization was defined as the percent loss of activity due to prestimulation; i.e.,

\section{Desensitization $=$

$$
\left(1-\frac{\text { ISO-induced cAMP from prestimulated cells }}{\text { ISO-induced cAMP from naive cells }}\right) \times 100 \%
$$

Sarcolemmal adenylyl cyclase activity. $36 \mathrm{~h}$ after adenoviral infection, membranes were prepared exactly as described above for radioligand binding, and protein concentration was measured. Adenylyl cyclase activity was determined by incubating $25 \mu \mathrm{g}$ of protein for $10 \mathrm{~min}$ at $37^{\circ} \mathrm{C}$ with no agonist (basal) or in the presence of $100 \mu \mathrm{M}$ ISO, $100 \mu \mathrm{M}$ zinterol, $10 \mathrm{mM} \mathrm{NaF}$, or $100 \mu \mathrm{M}$ forkolin. $\left[\alpha-{ }^{32} \mathrm{P}\right] \mathrm{ATP}$ was isolated and cAMP quantitated as we have described in reference
12. For a determination of $\mathrm{EC}_{50}$, increasing concentrations $\left(10^{-8} \mathrm{M}\right.$ up to $10^{-4} \mathrm{M}$ ) of ISO were incubated with sarcolemmal membranes as above.

Data analysis. Data represent the mean \pm SEM. The isoproterenol-cAMP dose-response curve was generated by GraphPad InPlot. The isoproterenol-adenylyl cyclase dose-response curve was generated by GraphPad Prism. $\beta$-Adrenergic receptor affinity for CYP was calculated using a nonlinear least squares fitting program (GraphPad Prism). To compare the statistical significance of the differences between the means of two independent groups, the Student's $t$ test with a two-tailed distribution was used. Calculations were done on Microsoft EXCEL.

\section{Results}

Cellular viability. In 20 fields, the mean number of myocytes in the respective dishes was: uninfected 1,537 \pm 185 ; Adeno$\beta A R K c t 1,515 \pm 208$; or Adeno- $\beta_{2}$ AR infected 1,477 $\pm 208(n=3$ plates, for each condition). Adenoviral infection did not alter the percentage of rod-shaped myocytes (uninfected $65 \pm 1 \%$; Adeno- $\beta$ ARKct $62 \pm 2 \%$; Adeno- $\beta_{2}$ AR $64 \pm 1 \%$ ). This contrasts with a marked decrease in the percentage of rod-shaped myocytes after incubation with norepinephrine for $48 \mathrm{~h}$ as previously demonstrated by Mann et al. (23).

Expression of transgenes. The three adenoviral constructs depicted in Fig. 1 were used in all infections and subsequent experiments. Robust expression of each adenoviral transgene was demonstrated after myocyte infection. As shown in Fig. 2 $A, 36 \mathrm{~h}$ after infection with Adeno- $\beta$ Gal at a moi of 100 and subsequent staining with $\mathrm{X}$-gal, nearly all the myocytes stained positive. Uninfected myocytes or those infected with Adeno$\beta_{2}$ AR or Adeno- $\beta$ ARKct remained colorless under these conditions. Radioligand binding documented marked overexpression of $\beta$-ARs after infection with Adeno- $\beta_{2}$ AR (Fig. 2 B). A dose-dependent effect is seen with increasing titers of Adeno$\beta_{2} \mathrm{AR}$ that reaches a maximal receptor density $(3,700 \pm 300$

\section{Recombinant Adenoviral Constructs}

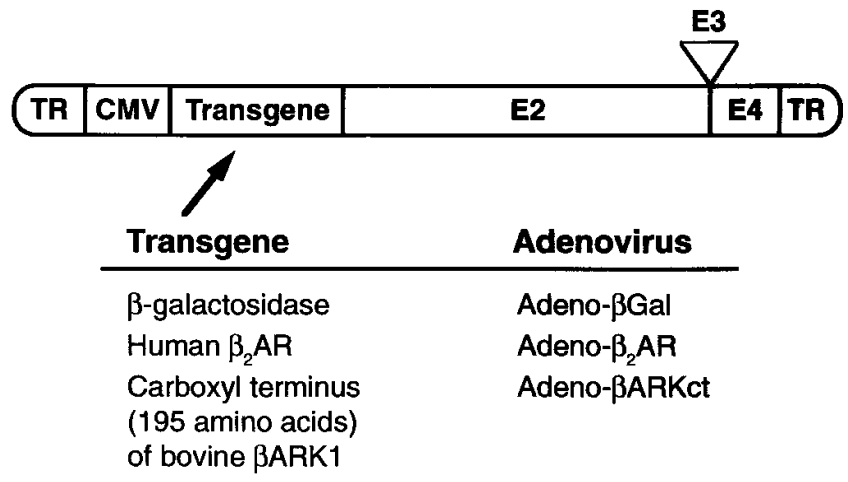

Figure 1. Diagram of recombinant adenoviral vectors. A first-generation adenoviral vector backbone (E1/E3 deletions) is ligated with the $\mathrm{CMV}$ promoter in front of the appropriate transgenes. Adeno- $\beta \mathrm{Gal}$ contains the $\beta$-galactosidase marker gene, Adeno- $\beta_{2}$ AR the human $\beta_{2} \mathrm{AR}$, and Adeno- $\beta$ ARKct the 195-amino acid carboxyl terminus peptide fragment of bovine $\beta$ ARK1 described in reference 17. Adeno-empty vector (not shown) contains no transgene. TR is the terminal repeat of the adenoviral vector and E2/E3/E4 represent the respective adenoviral genes. Full details of the construction of these vectors is given in the Methods section. 
A

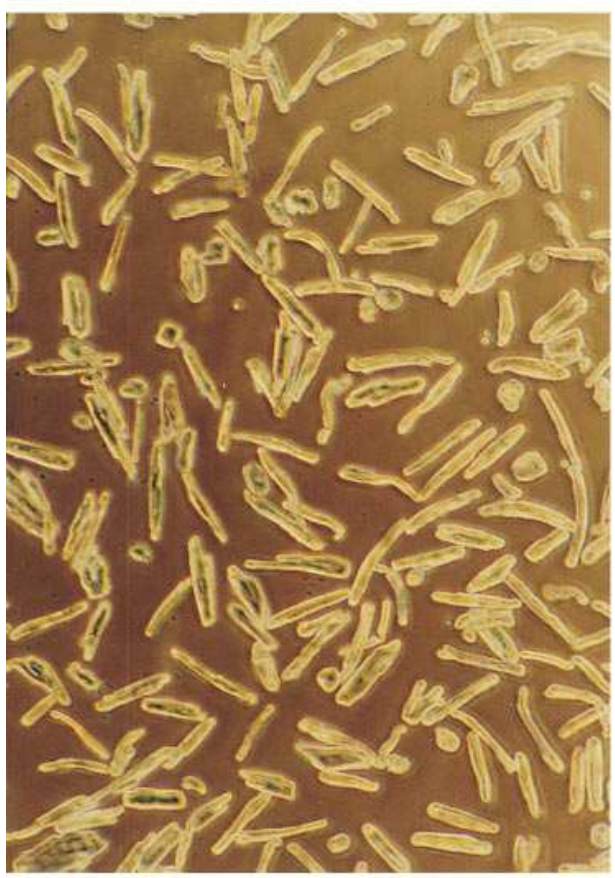

Control

B

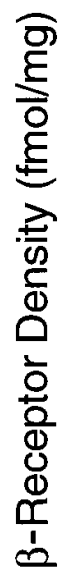

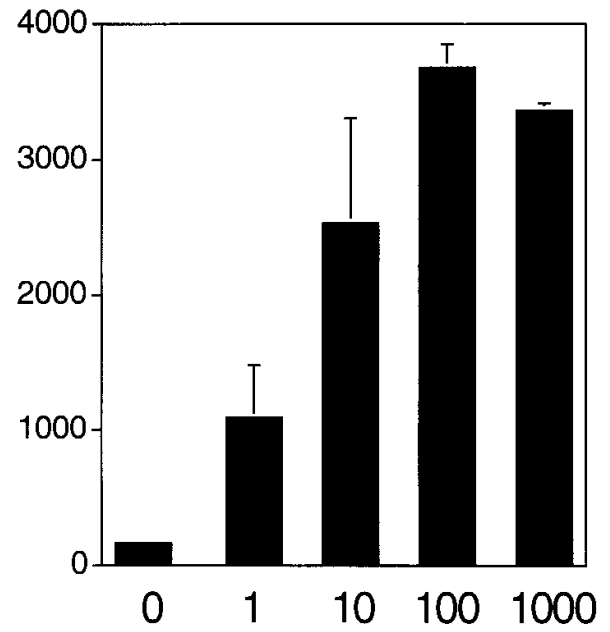

Multiplicity of Infection (MOI) of Adeno- $\beta_{2} A R$

C

MW (kD)

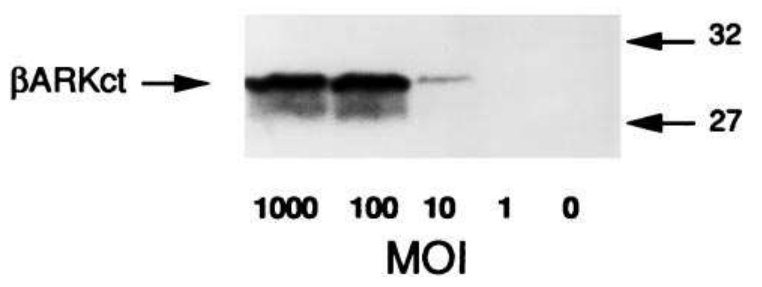

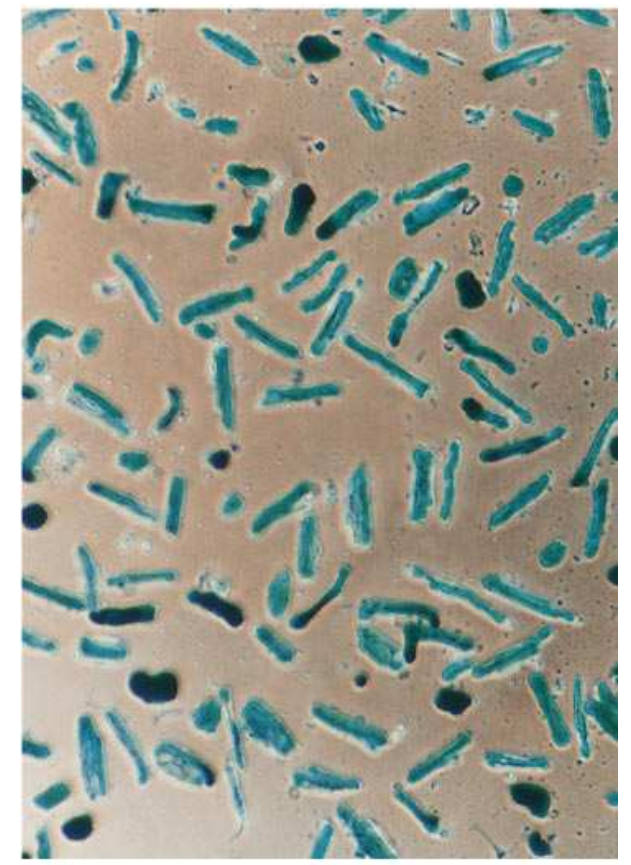

\section{Adeno- $\beta$ Gal}

Figure 2. Expression of recombinant adenoviral transgenes in adult rabbit ventricular myocytes. Myocytes were infected at a MOI of 100 for $36 \mathrm{~h} .(A)$ As assessed by X-gal staining, Adeno- $\beta$ Gal transduces $\sim 100 \%$ of myocytes (right) compared to uninfected (Control) myocytes (left) or those infected with Adeno- $\beta_{2} \mathrm{AR}$ or Adeno- $\beta$ ARKct. $(B)$ Radioligand binding assays with $\left[{ }^{125} \mathrm{I}\right]$ iodocyanopindolol performed on crude membranes from Adeno- $\beta_{2} \mathrm{AR}-$ infected myocytes demonstrate a viral titer-dependent expression of $\beta$-adrenergic receptors. The data represent the mean \pm SEM of four independent experiments, each performed in triplicate. (C) Protein immunoblots performed on cytosolic extracts from myocytes infected with the designated MOI of Adeno- $\beta$ ARKct. $5 \mu \mathrm{g}$ extracts were subjected to SDS-PAGE, probed with a $\beta A R K$ antiserum that recognizes the carboxyl terminus of $\beta$ ARK1, and detected with an alkaline phosphatase-conjugated rabbit antiserum. The arrow on the left points to the expected size band of $\beta$ ARKct, the carboxyl terminus fragment of $\beta A R K 1$ described in reference 17. The arrows on the right depict the position of the molecular mass standards in kilodaltons. 
A
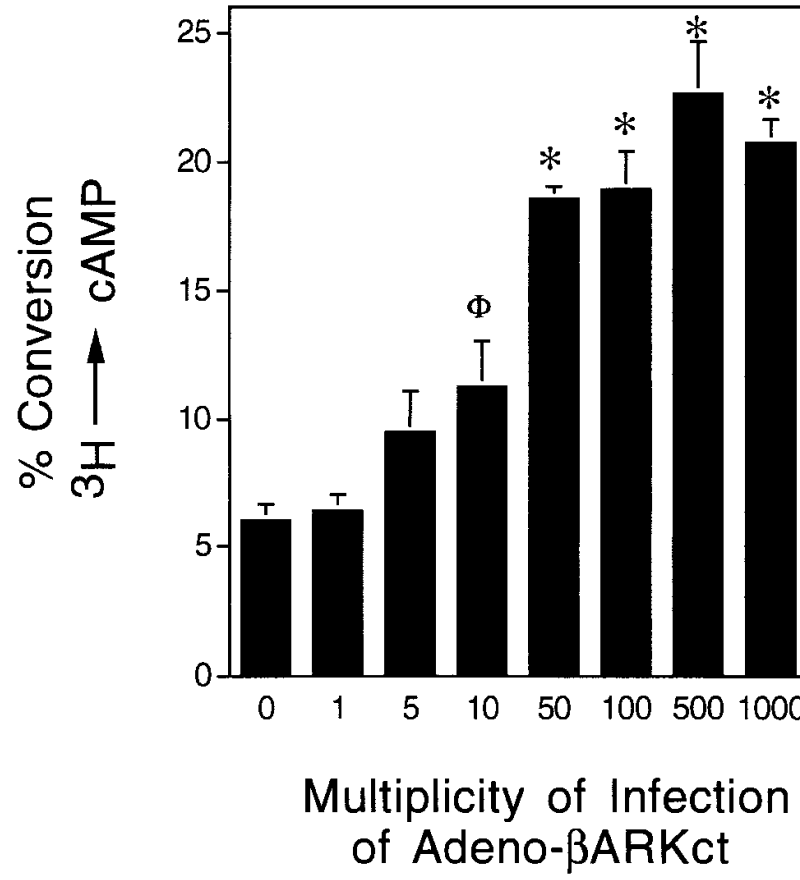

B

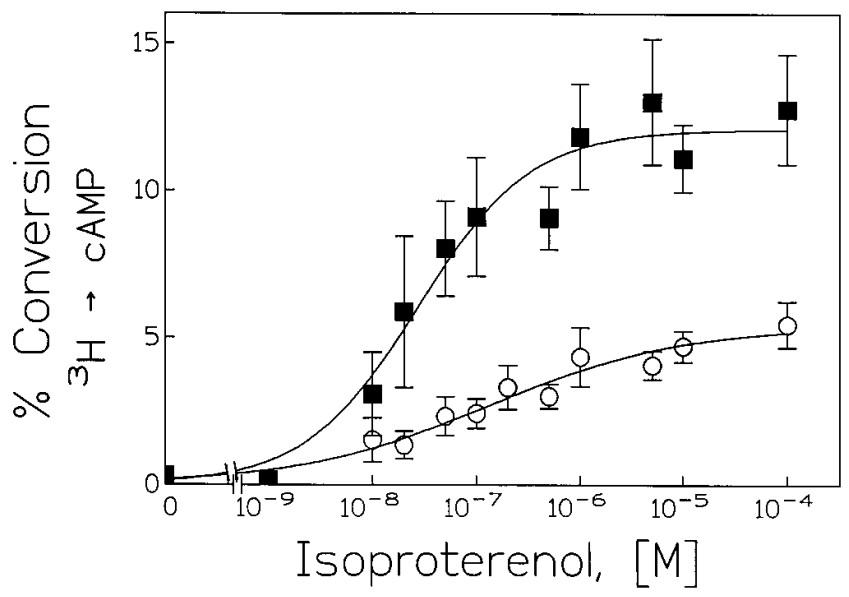

Figure 3. Isoproterenol-induced cAMP levels in Adeno- $\beta$ ARKctinfected myocytes. Experiments were performed $36 \mathrm{~h}$ after adenoviral infection. Myocytes are labeled overnight with $1.5 \mu \mathrm{Ci} / \mathrm{ml}\left[{ }^{3} \mathrm{H}\right] \mathrm{ad}$ enine, and preincubated for $30 \mathrm{~min}$ with IBMX. The accumulation of intracellular cAMP following ISO stimulation at $37^{\circ} \mathrm{C}$ is expressed as a percent conversion from total ${ }^{3} \mathrm{H}$ uptake. Shown is the effect of increasing moi of Adeno- $\beta$ ARKct $(A)$ or increasing concentration of ISO $(B)$. In $A$, myocytes were stimulated with $10 \mu \mathrm{M}$ ISO for $30 \mathrm{~min}$. In $B$, myocytes were infected with a moi 100 of Adeno- $\beta \mathrm{Gal}(\bigcirc)$ or Adeno- $\beta A R K c t(\boldsymbol{a})$ and stimulated with the designated concentration of ISO for $20 \mathrm{~min}$. In $B$, the basal values were determined from myocytes labeled with $10 \mu \mathrm{Ci} / \mathrm{ml}\left[{ }^{3} \mathrm{H}\right]$ adenine in preliminary experiments designed specifically to assess basal activity $(n=5)$. Infection

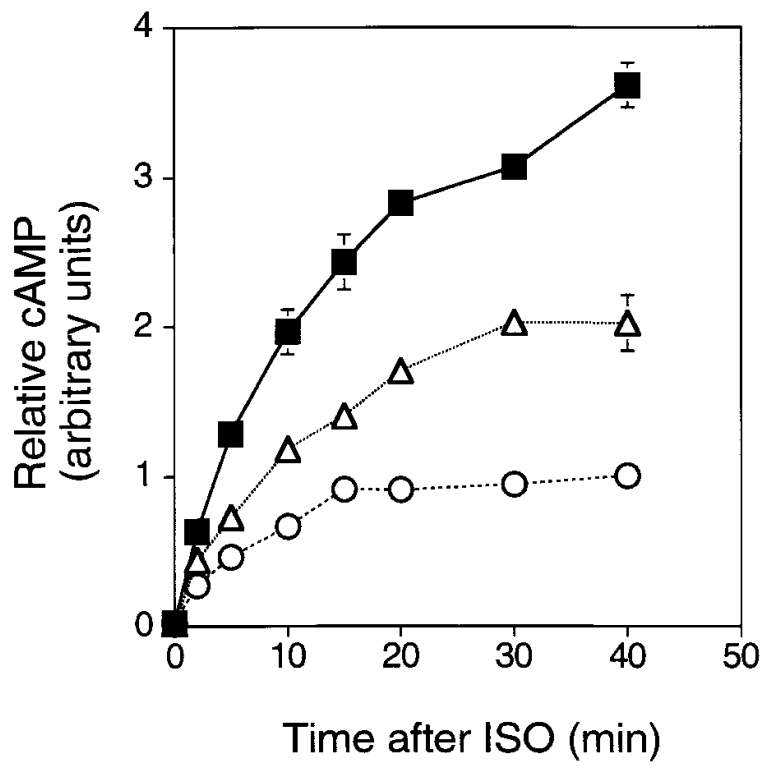

Figure 4. Time course of cAMP accumulation after exposure to 10 $\mu \mathrm{M}$ isoproterenol. Myocytes were infected with a moi 100 of Adeno$\beta G a l(\bigcirc)$, Adeno- $\beta_{2} A R(\triangle)$, or Adeno- $\beta A R K c t(\square)$ for $36 \mathrm{~h}$ and labeled overnight with $1.5 \mu \mathrm{Ci} / \mathrm{ml}\left[{ }^{3} \mathrm{H}\right]$ adenine. Intracellular cAMP was assayed as in Fig. 3. The maximum percent conversion of total ${ }^{3} \mathrm{H}$ uptake to cAMP in Adeno- $\beta \mathrm{Gal}-$ infected myocytes $(5.7 \pm 1 \%)$ is arbitrarily set at one, and all other data are expressed as relative values.

$\mathrm{fmol} / \mathrm{mg}$ membrane protein) with a moi of 100 . In contrast, infection with either Adeno- $\beta$ Gal or Adeno- $\beta A R K c t$ did not significantly alter $\beta$-AR density (uninfected $165 \pm 39$; Adeno$\beta$ Gal 131 \pm 23 ; Adeno- $\beta$ ARKct $134 \pm 30 \mathrm{fmol} / \mathrm{mg}$ membrane protein). There was no significant change in $\beta$-AR affinity for CYP $\left(K_{\mathrm{d}}\right.$, dissociation constant) $\left(K_{\mathrm{d}}\right)$ after infection with Adeno- $\beta_{2}$ AR $(26 \pm 8 \mathrm{pM})$ or Adeno- $\beta$ ARKct $(33 \pm 9 \mathrm{pM})$ versus Adeno- $\beta$ Gal $(31 \pm 10 \mathrm{pM})$. Protein immunoblotting with antiserum raised against the carboxyl terminus of $\beta$ ARK1 demonstrated expression of the novel, $\sim 30$-kD $\beta$ ARK peptide in myocytes infected with Adeno- $\beta A R K c t$ (Fig. $2 C$ ). Increasing titers of virus resulted in increased expression of protein with maximal expression at a moi of 100 . At a moi of one, a faint band was seen in an overexposed blot (data not shown). As expected, cytosolic extracts from uninfected myocytes or those infected with Adeno- $\beta$ Gal or Adeno- $\beta_{2}$ AR did not contain this band under any conditions. As assessed by protein immunoblots of myocyte membranes prepared $36 \mathrm{~h}$ after infection, transgene expression $\left(\beta_{2} \mathrm{AR}\right.$ or $\left.\beta \mathrm{ARKct}\right)$ did not alter levels of Gs or Gi (data not shown).

Effect of transgenes on $\beta$-adrenergic signaling in intact myocytes. As shown in Fig. $3 A$, we first assessed the effect of increasing titers of Adeno- $\beta$ ARKct on $10 \mu \mathrm{M}$ ISO-stimulated (30 min) intracellular cAMP levels. A moi of 50 led to near maximal potentiation of response versus uninfected myocytes $(19 \pm 1 \%$ vs. $6 \pm 1 \%, P<0.001)$. This is concordant with the re-

with Adeno- $\beta$ Gal (moi 5,000) or Adeno-empty vector (moi 1,000) had no effect on cAMP accumulation after 15 min of ISO stimulation (data not shown). The data represent the mean \pm SEM of three $(A)$ or four to five $(B)$ independent experiments, each performed in triplicate. ${ }^{\phi} P<0.05,{ }^{*} P<0.01$ vs. uninfected myocytes. 


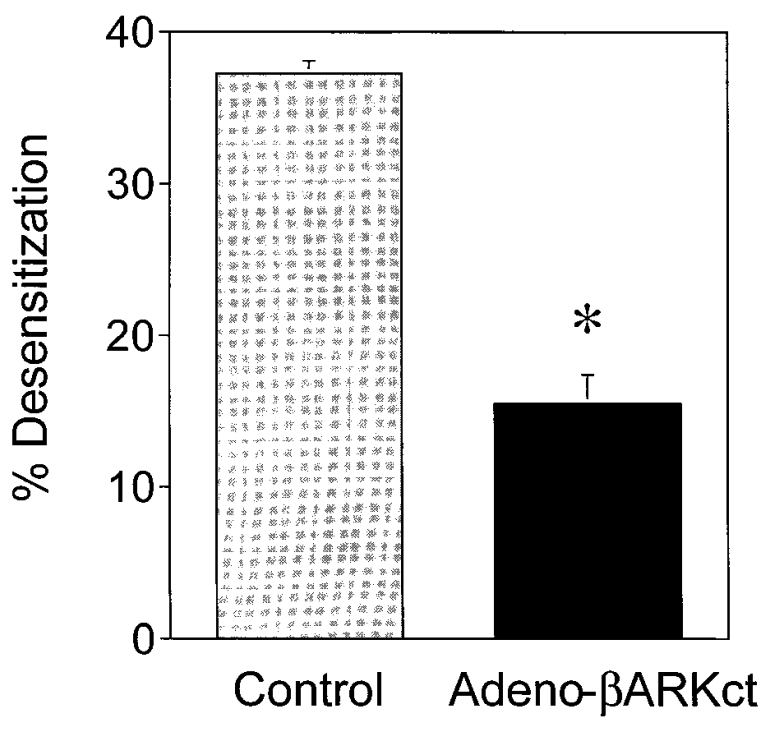

Figure 5. Desensitization in Adeno- $\beta$ Gal versus Adeno- $\beta$ ARKctinfected myocytes. ISO-induced cAMP accumulation was assayed as in Fig. 3 and was measured $36 \mathrm{~h}$ after infection with a MOI 100 of either Adeno- $\beta \mathrm{Gal}$ (Control) or Adeno- $\beta$ ARKct. To quantify desensitization, a prestimulation-restimulation approach was used in which cells were initially treated with or without agonist (10 $\mu \mathrm{M}$ ISO) for 10 min (prestimulated myocytes or naive myocytes, respectively). The response to a subsequent 3 min stimulation with $10 \mu \mathrm{M}$ ISO was compared. Desensitization, the percent loss of activity due to prestimulation (see Methods for calculations) was $37 \pm 1 \%$ in Adeno- $\beta \mathrm{Gal}$ (Control) myocytes (gray bar) and $16 \pm 2 \%$ in Adeno- $\beta$ ARKct myocytes (black bar). Data are the mean \pm SEM of four independent experiments, each in triplicate. Desensitization in Adeno- $\beta G$ al infected myocytes was not significantly different than in uninfected myocytes $(n=2$, data not shown). $* P<0.01$.

lationship of adenoviral titer and production of transgene protein (Fig. $2 C$ ). In contrast, myocytes that are uninfected, Adeno- $\beta$ Gal infected (moi up to 5,000), or Adeno-empty vector infected (moi 1,000) accumulate a nearly identical amount of cAMP following $15 \mathrm{~min}$ of ISO stimulation (data not shown). An ISO dose-response curve done in myocytes infected with a moi 100 of either Adeno- $\beta$ Gal or Adeno- $\beta$ ARKct (Fig. 3 B) also shows potentiation of $\beta$-AR signaling by Adeno- $\beta$ ARKct. After 20 min of stimulation with increasing concentrations of ISO, an increased $V_{\max }$ was seen in Adeno- $\beta$ ARKct-infected myocytes $(12 \pm 1 \%)$ as compared to Adeno- $\beta$ Gal-infected myocytes $(5.4 \pm 0.5 \%, P<0.05)$ as well as an approximately four fold leftward shift in the $\mathrm{EC}_{50}(100 \mathrm{nM}$ Adeno- $\beta \mathrm{Gal}$ vs. $28 \mathrm{nM}$ Adeno- $\beta$ ARKct).

To further assess the effect of Adeno- $\beta$ ARKct or Adeno$\beta_{2} \mathrm{AR}$ infection on the $\beta$-AR system, a time course of cAMP accumulation in response to ISO was conducted (Fig. 4). Basal cAMP level in Adeno- $\beta$ Gal-infected myocytes $(0.1 \%$ ) was unchanged by infection with Adeno- $\beta_{2}$ AR $(0.1 \pm 0.1 \%)$ or Adeno- $\beta A R K c t(0.1 \%)$. However, ISO-stimulated cAMP accumulation is increased at 5, 15, and $30 \mathrm{~min}$ after ISO versus control in myocytes infected with Adeno- $\beta_{2}$ AR (1.6 $\pm 0.1-$, $1.5 \pm 0.1-$, and $2.2 \pm 0.1$-fold) or Adeno- $\beta$ ARKct $(2.8 \pm 0.4-$, $2.7 \pm 0.1-$, and $3.3 \pm 0.2$-fold). In contrast, forskolin-stimulated cAMP accumulation is not significantly enhanced versus control (22\% conversion to cAMP) after infection with Adeno- $\beta_{2} \mathrm{AR}(1.2 \pm 0.1$-fold, $n=5$ ) or Adeno- $\beta$ ARKct (1.3 \pm 0.2 -fold, $n=6)$. The rate of accumulation of cAMP following ISO stimulation in Adeno- $\beta$ Gal myocytes rapidly diminishes such that from 15 to $30 \mathrm{~min}$ it has essentially plateaued (Fig. 4). In marked contrast, during this time interval (15-30 min) Adeno$\beta A R K c t-i n f e c t e d$ myocytes continue to accumulate significant rates of cAMP ( 0.05 relative cAMP U/min), comparable to the maximal rates seen in control myocytes $(0.06$ relative cAMP $\mathrm{U} / \mathrm{min}$ during the interval $0-15 \mathrm{~min}$ ). The prolongation of response to agonist after Adeno- $\beta$ ARKct infection is consistent with an acquired defect in desensitization.

Quantification of this desensitization defect is shown in Fig. 5. After prestimulation with $10 \mu \mathrm{M}$ ISO for $10 \mathrm{~min}$, desensitization is significantly inhibited in Adeno- $\beta$ ARKct-infected cells as compared to Adeno- $\beta$ Gal-infected cells $(P<0.001$, $n=4)$. Nearly identical data were obtained following a $3 \mathrm{~min}$ prestimulation with $10 \mu \mathrm{M}$ ISO (data not shown). Uninfected myocytes exhibited nearly the same level of desensitization $(35 \%)$ as Adeno- $\beta$ Gal-infected cells $(n=2)$ after a $10 \mathrm{~min}$ prestimulation with $10 \mu \mathrm{M}$ ISO.

Because the myocardium contains both $\beta_{1}$ and $\beta_{2}$ adrenergic receptors, we used selective antagonists to determine which receptor subtype would be affected by $\beta$ ARKct expression (Fig. 6). As previously shown in cultured myocytes (24), the $\beta_{1} \mathrm{AR}$ is the predominant mediator of ISO-induced cAMP ac-

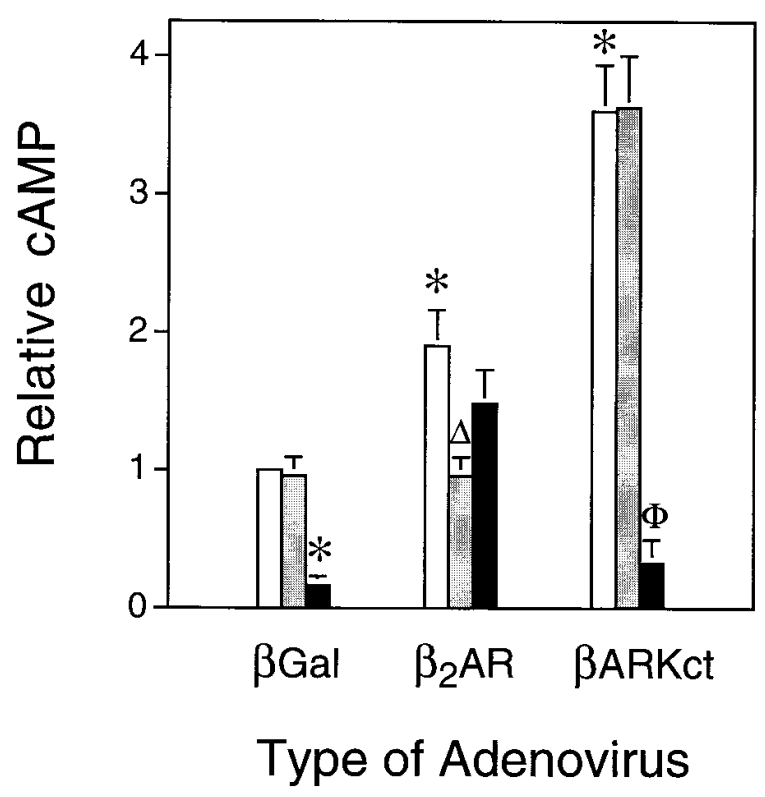

Figure 6. Effect of $\beta_{1}$ (ICI 89.406) or $\beta_{2}$ (ICI 118, 551) selective antagonists on ISO-induced cAMP levels. Myocytes were infected with a moi 100 of Adeno- $\beta$ Gal (left), Adeno- $\beta_{2}$ AR (middle), or Adeno$\beta$ ARKct (right) for $36 \mathrm{~h}$. Intracellular cAMP was assayed after a 20 min stimulation with $10 \mu \mathrm{M}$ ISO at $37^{\circ} \mathrm{C}$ in the absence of antagonists (white bars) and in the presence of ICI 118, 551, a selective $\beta_{2} \mathrm{AR}$ antagonist (gray bars) or ICI 89.406, a selective $\beta_{1} \mathrm{AR}$ antagonist (black bars). The percent conversion of total ${ }^{3} \mathrm{H}$ uptake to $\left[{ }^{3} \mathrm{H}\right] \mathrm{cAMP}$ after ISO stimulation in Adeno- $\beta$ GAl-infected myocytes (5.4 $\pm 1 \%$ ) is arbitrarily set at one (left, white bar), and all other data are expressed as relative values. Data represent the mean \pm SEM of three (ICI 89.406), four (ICI 188,551), or five (no antagonist) independent experiments, each in triplicate. ${ }^{*} P<0.05$ vs. Adeno- $\beta$ Gal no antagonist, ${ }^{\Delta} P<0.05$ vs. Adeno- $\beta_{2} \mathrm{AR}$ no antagonist, ${ }^{\Phi} P<0.01$ vs. Adeno- $\beta$ ARKct no antagonist. 
Table I. Adenylyl Cyclase Activity in Sarcolemmal Membranes from Adenoviral-infected Adult Rabbit Ventricular Myocytes

\begin{tabular}{lccccc}
\hline & Basal & $\begin{array}{c}\text { Isoproterenol } \\
(100 \mu \mathrm{M})\end{array}$ & $\begin{array}{c}\text { Zinterol } \\
(100 \mu \mathrm{M})\end{array}$ & $\begin{array}{c}\mathrm{NaF} \\
(10 \mathrm{mM})\end{array}$ & $\begin{array}{c}\text { Forskolin } \\
(100 \mu \mathrm{M})\end{array}$ \\
\hline Adeno- $\beta$ Gal & $36.9 \pm 3.1$ & $63.4 \pm 4.8$ & $48.0 \pm 4.0$ & $120 \pm 9.5$ & $223 \pm 13.6$ \\
Adeno- $\beta_{2}$ AR & $53.6 \pm 3.2^{*}$ & $104 \pm 6.7 *$ & $98.2 \pm 7.5 *$ & $122 \pm 8.2$ & $202 \pm 16.2$ \\
Adeno- $\beta$ ARKct $41.3 \pm 4.4$ & $73.8 \pm 8.8$ & $58.4 \pm 8.0$ & $121 \pm 11$ & $205 \pm 13.9$
\end{tabular}

Data represent $\mathrm{pmol} \mathrm{cAMP} / \mathrm{mg}$ protein $/ \mathrm{min} \pm \mathrm{SEM}, n=3-5$ cell isolations, assays done in duplicate. ${ }^{*} P<0.005$ vs. Adeno- $\beta$ Gal.

cumulation. Thus, in Adeno- $\beta$ Gal-infected (control) myocytes, the response to ISO is only minimally affected by ICI 118,551 , a $\beta_{2} \mathrm{AR}$ selective antagonist ( $\beta$ Gal, gray bar) but is significantly inhibited by ICI 89.406 , a $\beta_{1}$ AR selective antagonist $\left(\beta G a l\right.$, black bar). After infection with Adeno- $\beta_{2} \mathrm{AR}$, there is a 1.9 \pm 0.2 -fold potentiation of ISO-induced cAMP levels $\left(\beta_{2} A R\right.$, white bar $)$. ICI 118, 551 reduces the accumulation of cAMP back to control levels, presumably by blocking exogenous $\beta_{2}$ ARs $\left(\beta_{2} A R\right.$, gray bar $)$. This experiment demonstrates that $100 \mathrm{nM}$ ICI 118,551 effectively blocks the $\beta_{2}$ AR-mediated response. Since the same concentration of ICI 118,551 has little effect on diminishing the cAMP response in Adeno- $\beta$ ARKctinfected cells ( $\beta A R K c t$, gray bar), this strongly suggests that the enhanced cAMP accumulation following $\beta$ ARKct expression is mediated via $\beta_{1}$ ARs. Supporting this hypothesis is the effect of ICI 89.406, the $\beta_{1}$ AR antagonist, which effectively attenuates this signal ( $\beta A R K c t$, black bar).

Effect of transgenes on $\beta$-adrenergic signaling in myocyte sarcolemmal membranes. Adeno- $\beta_{2} \mathrm{AR}$ infection significantly increased both basal cyclase activity $(53.6 \pm 3.2 \mathrm{pmol} \mathrm{cAMP} /$ $\mathrm{mg} / \mathrm{min}$ ) versus control (Adeno- $\beta \mathrm{Gal}, 36.9 \pm 3.1 \mathrm{pmol} / \mathrm{mg} / \mathrm{min}$, $P<0.005)$ and ISO-stimulated cyclase $(104 \pm 6.7 \mathrm{pmol} \mathrm{cAMP} /$ $\mathrm{mg} / \mathrm{min})$ versus control $(63.4 \pm 4.8 \mathrm{pmol} / \mathrm{mg} / \mathrm{min}, P<0.005)$ (Table I). Consistent with this effect being mediated through the $\beta_{2} \mathrm{AR}$, the stimulation of adenylyl cyclase by zinterol, a selective $\beta_{2} \mathrm{AR}$ agonist, is also significantly increased in Adeno$\beta_{2} \mathrm{AR}$-infected myocytes $(98.2 \pm 7.5 \mathrm{pmol} \mathrm{cAMP} / \mathrm{mg} / \mathrm{min})$ versus control ( $48 \pm 4 \mathrm{pmol} / \mathrm{mg} / \mathrm{min}, P<0.005$ ). This potentiation of $\beta$-adrenergic signaling does not appear to be secondary to changes in either $G$ proteins or adenylyl cyclase as the response to $\mathrm{NaF}$ or Forskolin is unchanged by Adeno- $\beta_{2} \mathrm{AR}$ infection (Table I). An ISO-adenylyl cyclase dose-response curve did not show significantly enhanced agonist potency $\left(\mathrm{EC}_{50}\right)$ after Adeno- $\beta_{2} \mathrm{AR}$ infection $(48 \mathrm{nM})$ versus control (59 $\mathrm{nM})$.

Similar to that demonstrated in transgenic mice (12), the Adeno- $\beta$ ARKct transgene does not enhance $\beta$-adrenergic agonist stimulation (either ISO or zinterol) of membrane adenylyl cyclase versus control. This result is expected since $\beta$ ARKct is a cytosolic peptide that is not present in the membrane fraction (12). Infection with Adeno- $\beta A R K c t$ also does not affect the response of membrane adenylyl cyclase to $\mathrm{NaF}$ or forskolin as compared to control.

\section{Discussion}

A number of alterations in the myocardial $\beta$-adrenergic pathway occur in patients with congestive heart failure including downregulation of $\beta_{1} \operatorname{ARs}(8,9,25)$, uncoupling of the remain- ing $\beta$-ARs from adenylyl cyclase (7), and increased expression of $\beta$ ARK1 $(9,10)$, an enzyme that phosphorylates and uncouples only agonist-bound receptors (26) including the $\beta_{1}$ AR (27, 28 ). Our laboratory has been studying the feasibility of reversing these alterations in the $\beta$-adrenergic cascade to restore cardiac inotropy to normal in patients with depressed systolic function. Transgenic mice that overexpress the human $\beta_{2} \mathrm{AR}$ under control of the cardiac specific $\alpha$-myosin heavy chain promoter have a basal cardiac inotropy that rivals that achieved in wild-type mice after maximal ISO stimulation (11). Likewise, transgenic mice with cardiac overexpression of an inhibitor of $\beta A R K$ ( $\beta A R K c t)$ have increased basal contractility and an enhanced response to ISO (12).

Having established that cardiac function can be enhanced in transgenic mice by overexpression of either $\beta_{2}$ ARs or an inhibitor of $\beta A R K$, we are now attempting to use recombinant adenovirus encoding these transgenes to potentiate $\beta$-adrenergic signaling. This paper is the initial report of these efforts using a cell culture model consisting of adult rabbit ventricular myocytes. The relevance of a primary cardiomyocyte culture model is highlighted by the demonstration that isolated myocytes from human patients with CHF have demonstrable deficiencies in response to $\beta$-agonist stimulation (29). As others have shown $(20,30)$, we have found adenovirus to achieve $\sim 100 \%$ transduction efficiency as assessed by X-gal staining (Fig. $2 A$ ). We also have demonstrated robust transgene expression after infection with Adeno- $\beta_{2} \mathrm{AR}$ as assessed by radioligand binding (Fig. $2 \mathrm{~B}$ ) and Adeno- $\beta$ ARKct by protein immunoblots (Fig. $2 C$ ). As has been seen previously with chloramphenicol acetyltransferase or $\beta$-galactosidase $(20,30)$, expression of both the $\beta_{2} \mathrm{AR}$ and $\beta \mathrm{ARKct}$ transgenes is dependent upon viral titer, and with our vector reaches a maximum at a moi between 50 and 100 .

After adenoviral infection, $\beta$-adrenergic signaling was assessed by the accumulation of intracellular cAMP in the intact myocyte or by activation of adenylyl cyclase in sarcolemmal membranes. Infection with Adeno- $\beta_{2} A R$ potentiated the $\beta$-adrenergic signal as assessed both by the intracellular cAMP response (Fig. 4) and by membrane adenylyl cyclase activity (Table I). Evidence that the potentiated signal following Adeno- $\beta_{2} A R$ infection is mediated via $\beta_{2}$-adrenergic receptors includes the inhibition of the increased ISO-stimulated cAMP response by a selective $\beta_{2}$-adrenergic antagonist (Fig. 6) and the significantly increased stimulation of cyclase activity versus control by zinterol, a selective $\beta_{2}$-adrenergic agonist (Table I). While it might have been expected that the $\mathrm{EC}_{50}$ for isoproterenol stimulation of adenylyl cyclase would have been left shifted after $\beta_{2}$-adrenergic receptor overexpression, this was not observed. This most likely relates to the relatively modest overexpression of receptors in these experiments. In myocardial membranes from transgenic animals expressing very high concentrations of receptors (20-40 pmol/mg) (11), a 10-fold shift was observed. In animals expressing $\sim 1.2 \mathrm{pmol} / \mathrm{mg}$, about a fourfold shift was found (31). By contrast, in the isolated myocytes used for the experiments in which we determined $\mathrm{EC}_{50}$ 's for isoproterenol, only $\sim 600 \mathrm{fmol} / \mathrm{mg}$ of $\beta_{2^{-}}$ adrenergic receptors were present.

Infection with Adeno- $\beta$ ARKct also potentiated $\beta$-adrenergic signaling in the intact myocyte, but its effect was mediated via the $\beta_{1}$-adrenergic receptor (Fig. 6). Notably, Adeno$\beta A R K c t$ infection does not affect $\beta$-adrenergic stimulation as assessed by membrane adenylyl cyclase activity (Table I). 
These results are in agreement with previously published data from transgenic mice that overexpress the identical transgene and are to be expected because $\beta$ ARKct is a cytosolic peptide that is not present in the membrane fraction (12). Furthermore, these data strongly suggest that the potentiation of $\beta_{1^{-}}$ adrenergic signaling by Adeno- $\beta$ ARKct in the intact myocyte is not secondary to a change in expression of a membrane component of the $\beta$-adrenergic cascade (e.g., G proteins or adenylyl cyclase) in which case enhanced $\beta$-adrenergic stimulation of sarcolemmal adenylyl cyclase also should have been seen.

As predicted, the mechanism of potentiation of $\beta_{1}$ AR signaling by Adeno- $\beta$ ARKct involves inhibition of receptor desensitization. $\beta A R K c t$ is a 195-amino acid carboxyl terminus peptide fragment of bovine $\beta$ ARK1 that contains the $G_{\beta \gamma}$ binding domain. It presumably sequesters dissociated $\mathrm{G}_{\beta \gamma}$, preventing it from recruiting $\beta A R K 1$ to the membrane, and thus inhibits $\beta A R K$ phosphorylation of its activated receptor substrate. These actions of the carboxyl terminal peptide of $\beta A R K 1$ have been well characterized previously in vitro (17, $32,33)$. In this study, Adeno- $\beta A R K c t$ inhibition of desensitization was documented in two ways. In a time course experiment of cAMP accumulation following ISO stimulation, the ability of myocytes infected with Adeno- $\beta A R K c t$ to respond to ISO persisted far longer than in the control myocytes (Fig. 4). In a second set of experiments, using a prestimulation-restimulation approach to quantitate desensitization, Adeno- $\beta$ ARKct infection was again shown to significantly inhibit this process (Fig. 5). Because individual cell types have different mechanisms of desensitization (34), these experiments are informative by showing that in rabbit ventricular myocytes $G_{\beta \gamma}$ activation of $\beta A R K$ plays a central role in desensitization of the $\beta_{1} A R$.

Several other potential mechanisms for the enhanced $\beta$-adrenergic signal after infection with Adeno- $\beta_{2} \mathrm{AR}$ or Adeno- $\beta \mathrm{ARKct}$ were excluded. Unlike a prior report based on neonatal myocytes (35), adenoviral infection did not enhance $\beta$-adrenergic signaling per se since there was no difference in the amount of ISO-stimulated cAMP between uninfected myocytes and those infected with high titers of Adeno- $\beta$ Gal or Adenoempty vector. Adeno- $\beta_{2}$ AR or Adeno- $\beta$ ARKct infection did not significantly affect levels of $G$ proteins as determined by protein immunoblots and by the adenylyl cyclase response after NaF stimulation, nor did the transgenes significantly increase levels of adenylyl cyclase as assessed by its response to forskolin stimulation (Table I). As expected, Adeno- $\beta$ ARKct also did not increase expression of the $\beta$-adrenergic receptor.

In conclusion, recombinant adenoviral infection leading to overexpression of the $\beta_{2} \mathrm{AR}$ or an inhibitor of $\beta \mathrm{ARK}$-mediated desensitization can potentiate $\beta$-adrenergic signaling in cultured adult rabbit ventricular myocytes. We emphasize that large hurdles remain before genetic modulation of the $\beta$-adrenergic system can be considered a potential therapy for patients with systolic dysfunction. These hurdles include extending the limited duration of expression of recombinant adenoviral transgenes (36), obtaining global myocardial delivery of the adenovirus presumably via coronary artery injection (37), and demonstrating a hemodynamic and survival benefit in animal models of $\mathrm{CHF}$.

\section{Acknowledgments}

We thank Greg Heintz, Chad Brown, Christine Skaer, and Kyle Shotwell for excellent technical assistance, Ronda Baldwin for expertise in myocyte isolation, and Dr. Neil Freedman for helpful discussions throughout this study.

This work was supported in part by National Institutes of Health grants T32HL07101 (to M.H. Drazner), HL32708-12 (to A.O. Grant), and HL-16037 (to R.J. Lefkowitz).

\section{References}

1. Hartzell, H.C., P.-F. Méry, R. Fischmeister, and G. Szabo. 1991. Sympathetic regulation of cardiac calcium current is due exclusively to cAMP-dependent phosphorylation. Nature (Lond.). 351:573-576.

2. Rapundalo, S.T., R.J. Solaro, and E.G. Kranias. 1989. Inotropic responses to isoproterenol and phosphodiesterase inhibitors in intact guinae pig hearts: comparison of cyclic AMP levels and phosphorylation of sarcoplasmic reticulum and myofibrillar proteins. Circ. Res. 64:104-111.

3. Brodde, O.-E. 1993. Beta-adrenoceptors in cardiac disease. Pharmacol. Ther. 60:405-430.

4. Xiao, R.-P., and E.G. Lakatta. 1993. $\beta_{1}$-adrenoceptor stimulation and $\beta_{2}$ adrenoceptor stimulation differ in their effects on contraction, cytosolic $\mathrm{Ca}^{2+}$, and $\mathrm{Ca}^{2+}$ current in single rat ventricular cells. Circ. Res. 73:286-300.

5. Xiao, R.-P., C. Hohl, R. Altschuld, L. Jones, B. Livingston, B. Ziman, B. Tantini, and E.G. Lakatta. 1994. $\beta_{2}$-adrenergic receptor-stimulated increase in cAMP in rat heart cells is not coupled to changes in $\mathrm{Ca}^{2+}$ dynamics, contractility, or phospholamban phosphorylation. J. Biol. Chem. 269:19151-19156.

6. Garg, R., M. Packer, B. Pitt, and S. Yusuf. 1993. Heart failure in the 1990s: evolution of a major public health problem in cardiovascular medicine. $J$. Am. Coll. Cardiol. 22(Suppl. A):3A-5A.

7. Bristow, M.R., R. Ginsburg, W. Minobe, R.S. Cubicciotti, W.S. Sageman, K. Lurie, M.E. Billingham, D.C. Harrison, and E.B. Stinson. 1982. Decreased catecholamine sensitivity and $\beta$-adrenergic-receptor density in failing human hearts. N. Engl. J. Med. 307:205-211.

8. Bristow, M.R., R. Ginsburg, V. Umans, M. Fowler, W. Minobe, R. Rasmussen, P. Zera, R. Menlove, P. Shah, S. Jamieson, et al. 1986. $\beta_{1}$ - and $\beta_{2}$-Adrenergic-receptor subpopulations in nonfailing and failing human ventricular myocardium: coupling of both receptor subtypes to muscle contraction and selective $\beta_{1}$-receptor down-regulation in heart failure. Circ. Res. 59:297-309.

9. Ungerer, M., M. Böhm, J.S. Elce, E. Erdmann, and M.J. Lohse. 1993. Altered expression of $\beta$-adrenergic receptor kinase and $\beta_{1}$-adrenergic receptors in the failing human heart. Circulation. 87:454-463.

10. Ungerer, M., G. Parruti, M. Böhm, M. Puzicha, A. DeBlasi, E. Erdmann, and M.J. Lohse. 1994. Expression of $\beta$-arrestins and $\beta$-adrenergic receptor kinases in the failing human heart. Circ. Res. 74:206-213.

11. Milano, C.A., L.F. Allen, H.A. Rockman, P.C. Dolber, T.R. McMinn, K.R. Chien, T.D. Johnson, R.A. Bond, and R.J. Lefkowitz. 1994. Enhanced myocardial function in transgenic mice overexpressing the $\beta_{2}$-adrenergic receptor. Science (Wash. DC). 264:582-586.

12. Koch, W.J., H.A. Rockman, P. Samama, R. Hamilton, R.A. Bond, C.A Milano, and R.J. Lefkowitz. 1995. Cardiac function in mice overexpressing the $\beta$-adrenergic receptor kinase or a $\beta$ ARK inhibitor. Science (Wash. DC). 268 : 1350-1353.

13. Grant, A.O., M.A. Dietz, F.R. Gilliam, and C.F. Starmer. 1989. Blockade of cardiac sodium channels by lidocaine: single-channel analysis. Circ. Res. 65:1247-1262.

14. Nair, L.A., J. Inglese, R. Stoffel, W.J. Koch, R.J. Lefkowitz, M.M Kwatra, and A.O. Grant. 1995. Cardiac muscarinic potassium channel activity is attenuated by inhibitors of $\mathrm{G}_{\beta \gamma}$. Circ. Res. 76:832-838.

15. Kolls, J., K. Peppel, M. Silva, and B. Beutler. 1994. Prolonged and effective blockade of tumor necrosis factor activity through adenovirus-mediated gene transfer. Proc. Natl. Acad. Sci. USA. 91:215-219.

16. Andersson, S., D.L. Davis, H. Dahlbäck, H. Jörnvall, and D.W. Russell. 1989. Cloning, structure, and expression of the mitochondrial cytochrome P-450 Sterol 26-hydroxylase, a bile acid biosynthetic enzyme. J. Biol. Chem. 264:82228229 .

17. Koch, W.J., B.E. Hawes, J. Inglese, L.M. Luttrell, and R.J. Lefkowitz. 1994. Cellular expression of the carboxyl terminus of a $G$ protein-coupled receptor kinase attenuates $\mathrm{G}_{\beta \gamma}$-mediated signaling. J. Biol. Chem. 269:6193-6197.

18. Graham, F.L., J. Smiley, W.C. Russell, and R. Nairn. 1977. Characteristics of a human cell line transformed by DNA from human adenovirus type 5.J. Gen. Virol. 36:59-74.

19. Gerdes, A.M., J. Kriseman, and S.P. Bishop. 1982. Morphometric study of cardiac muscle: the problem of tissue shrinkage. Lab. Invest. 46:271-274.

20. Kass-Eisler, A., E. Falck-Pedersen, M. Alvira, J. Rivera, P.M. Buttrick, B.A. Wittenberg, L. Cipriani, and L.A. Leinwand. 1993. Quantitative determination of adenovirus-mediated gene delivery to rat cardiac myocytes in vitro and in vivo. Proc. Natl. Acad. Sci. USA. 90:11498-11502.

21. Bradford, M.M. 1976. A rapid and sensitive method for the quantitation of microgram quantities of protein utilizing the principle of protein-dye binding. Anal. Biochem. 72:248-254.

22. Salomon, Y., C. Londos, and M. Rodbell. 1974. A highly sensitive adenylate cyclase assay. Anal. Biochem. 58:541-548. 
23. Mann, D.L., R.L. Kent, B. Parsons, and G. Cooper. 1992. Adrenergic effects on the biology of the adult mammalian cardiocyte. Circulation. 85:790804.

24. Altschuld, R.A., R.C. Starling, R.L. Hamlin, G.E. Billman, J. Hensley, L. Castillo, R.H. Fertel, C.M. Hohl, P.-M.L. Robitaille, L.R. Jones, et al. 1995 Response of failing canine and human heart cells to $\beta_{2}$-adrenergic signaling. Circulation. 92:1612-1618.

25. Bristow, M.R., W.A. Minobe, M.V. Raynolds, J.D. Port, R. Rasmussen, P.E. Ray, and A.M. Feldman. 1993. Reduced $\beta_{1}$ receptor messenger RNA abundance in the failing human heart. J. Clin. Invest. 92:2737-2745.

26. Benovic, J.L., R.H. Strasser, M.G. Caron, and R.J. Lefkowitz. 1986. $\beta$-adrenergic receptor kinase: identification of a novel protein kinase that phosphorylates the agonist-occupied form of the receptor. Proc. Natl. Acad. Sci. USA. 83:2797-2801.

27. Freedman, N.J., S.B. Liggett, D.E. Drachman, G. Pei, M.G. Caron, and R.J. Lefkowitz. 1995. Phosphorylation and desensitization of the human $\beta_{1}$ adrenergic receptor: involvement of $\mathrm{G}$ protein-coupled receptor kinases and cAMP-dependent protein kinase. J. Biol. Chem. 270:17953-17961.

28. Zhou, X.-M., M. Pak, Z. Wang, and P.H. Fishman. 1995. Differences in desensitization between human $\beta_{1^{-}}$and $\beta_{2}$-adrenergic receptors stably expressed in transfected hamster cells. Cell. Signalling. 7:207-217.

29. Davies, C.H., K. Davia, J.G. Bennett, J.R. Pepper, P.A. Poole-Wilson, and S.E. Harding. 1995. Reduced contraction and altered frequency response of isolated ventricular myocytes from patients with heart failure. Circulation. 92: 2540-2549.

30. Kirshenbaum, L.A., W.R. MacLellan, W. Mazur, B.A. French, and
M.D. Schneider. 1993. Highly efficient gene transfer into adult ventricular myocytes by recombinant adenovirus. J. Clin. Invest. 92:381-387.

31. Turki, J., J.N. Lorenz, S.A. Green, E.T. Donnelly, M. Jacinto, and S.B. Liggett. 1996. Myocardial signaling defects and impaired cardiac function of a human $\beta_{2}$-adrenergic receptor polymorphism expressed in transgenic mice. Proc. Natl. Acad. Sci. USA. 93:10483-10488.

32. Koch, W.J., J. Inglese, W.C. Stone, and R.J. Lefkowitz. 1993. The binding site for the $\beta \gamma$ subunits of heterotrimeric $\mathrm{G}$ proteins on the $\beta$-adrenergic receptor kinase. J. Biol. Chem. 268:8256-8260.

33. Touhara, K., W.J. Koch, B.E. Hawes, and R.J. Lefkowitz. 1995. Mutational analysis of the pleckstrin homology domain of the $\beta$-adrenergic receptor kinase. J. Biol. Chem. 270:17000-17005.

34. Shih, M., and C.C. Malbon. 1994. Oligodeoxynucleotides antisense to mRNA encoding protein kinase $A$, protein kinase $C$, and $\beta$-adrenergic receptor kinase reveal distinctive cell-type-specific roles in agonist-induced desensitization. Proc. Natl. Acad. Sci. USA. 91:12193-12197.

35. Novotny, J., B. Gustafson, P. Kvapil, and L.A. Ransnäs. 1994. Adenovirus infection of myocardial cells induces an enhanced sensitivity to $\beta$-adrenergic agonists by increasing the concentration of the stimulatory G-protein. Biochem. Mol. Biol. Int. 34:993-1001.

36. Yang, Y., F.A. Nunes, K. Berencsi, E.E. Furth, E. Gönczöl, and J.M. Wilson. 1994. Cellular immunity to viral antigens limits E1-deleted adenoviruses for gene therapy. Proc. Natl. Acad. Sci. USA. 91:4407-4411.

37. Barr, E., J. Carroll, A.M. Kalynych, S.K. Tripathy, K. Kozarsky, J.M Wilson, and J.M. Leiden. 1994. Efficient catheter-mediated gene transfer into the heart using replication-defective adenovirus. Gene Ther. 1:51-58. 